\title{
Rainforestation and Sustainable Development: From the Lens of the Four Individual Adopters from the Visayas Region in the Philippines
}

\author{
Guiraldo C. Fernandez and Marlito Jose M. Bande \\ Visayas State University \\ guiraldo.fernandez@vsu.edu.ph
}

\section{Abstract}

Rainforestation (RF) is a reforestation strategy designed to address the problem of dwindling Philippine forest landscapes by planting native trees to unproductive and idle lands. It was introduced in the early 1990's to ensure that forests only have species that are endemic in the country. Using the method of hermeneutic phenomenology, this paper concludes that the Philippine indigenous tree species have enhanced the viability of Rainforestation as a major conservation strategy in the Philippines as compared to the exotic trees used by the government in the 1970s and 1980s and therefore, is very significant in promoting biodiversity and sustainable development.

Keywords: environment conservation, economic, environmental and social benefits

\subsection{Introduction}

Biodiversity in the Philippines is one of the richest in the world. It is part of the 17 mega diverse countries which collectively claim two thirds of all global species. Yet, $70 \%$ of Philippine forests have vanished from the 1930s to 1988 (Haribon Foundation, 2016). There are two major causes of Philippine forests loss. They refer to the conversion of primary forests to secondary forests by both legal and illegal logging as well as the removal of secondary forests cover by expansion of upland agriculture (Fernando, Rainforestation: A strategy for restoring our dying forests, 2005). Yet, though rampant deforestation has already been prevalent in the Philippines, the government has not been able to effectively address the problem (Kalikasan People's Network, 2017). Not only that, decades of long reforestation efforts using fast growing exotic species had led to the alteration of Philippine rainforests into simply forests plantation which failed to bring back ecosystem functions(Fernando, Restoring the Philippine Rainforest, 2005). After all, exotic trees cannot replace Philippine native trees because they are not suited to Philippine climate (Ranada, 2014).

Hence, to answer this problem of rehabilitating denuded lands, the Visayas State University introduced Rainforestation in the early 1990's. Rainforestation is a technology designed to make use of unproductive lands by planting native tree species which are not widely used in the Philippine government's reforestation program (Milan \&Ceniza, 2009).This technology found its way to Visayas State University in 1990. The Philippine-German Applied Tropical Ecology Project started to look into possibilities of rehabilitating former forested areas 
to reclaim the ecological functions of the degraded areas needed for poverty alleviation through sustainable rural development. This program was designed for the promotion of biodiversity rehabilitation, conservation of remaining primary forests and natural resources, and the development of a closed canopy and high diversity forest farming system called Rainforestation. The directives of the program were formulated so that Rainforestation could replace the wide spread slash-and-burn practices and protect and enhance biodiversity by using indigenous trees only. In 1994 the hypothesis was formulated that a farming system in the humid tropics is increasingly more sustainable the closer it is in its species composition to the original local rainforest (Goltenbot, 2005). With this, the ecological functions of a given ecosystem were re-established while subsistence farmers were provided with a stable and long-term income.

Hence, Rainforestation was conceived as an environment conservation strategy. Aside from that, it also enabled willing adopters and farmers to sustain themselves economically. Since its implementation in the mid-1990s, a number of studies have proven that Rainforestation served as instrument in attaining the above-mentioned benefits. For instance, Asio and Milan (2002) had claimed that Rainforestation had greatly improved soil quality in degraded lands. This claim had been supported by the findings of the study of Pinho, Miller and Alfaia (2012) which asserted that greater diversity of trees planted in denuded lands had led to positive effects in terms of the land's fertility. The litters produced by trees had led to a greater maintenance of soil biodiversity which had great positive effects on soil fertility. Soil improvement under trees had been in great part related to the increases of organic matter in the form of surface leaf litters. With the results of the study of Pinho, Miller and Alfaia (2012), Asio and Milan's (2002) claim that Rainforestation was not only an effective reforestation strategy but also effective in restoring soil quality found a logical basis that validated the conclusion of their research conducted ten years earlier. Hence, the improved soil quality indubitably had helped willing adopters and farmers in their quest for food security since it paved the way for the success of the production of shade-loving agronomic crops in canopy gaps in Rainforestation farms. With the study's findings, it was proven that Rainforestation had been a sound approach to reforestation since it did not only restore natural vegetation but also provided farmers and willing adopters some income from the agronomic crops because of the improved soil quality. In addition, the claim that Rainforestation had been capable of improving soil fertility in denuded lands had also been affirmed by the Rainforestation adopters from a farmers' People's Organization in Baybay, Leyte(Fernandez \& Bande, "Rainforestation implementation and Durkheim's Notion of Mechanical Solidarity: From the experiences of the pioneering adopters of the Cienda San Vicente Farmers Association in Baybay City, Leyte", 2018). Such study had asserted that the growth of fruit trees had also been a contributory factor in bringing back soil biodiversity. It brought back soil fertility in denuded and unproductive lands.

Moreover, Goltenboth (2011) claims that Rainforestation is also an appropriate and ecological approach for landscape rehabilitation and impact mitigation of climate change in the humid tropics. It showed that Rainforestation has been very instrumental in the preservation of dwindling watershed areas. It has enabled watersheds to naturally serve its purpose of providing the entire essential ecological functions by keeping the middle and lowlands as well as the coastal areas intact as major productive areas for rural populations. They are, by their aquatic nature, more sustainable as they function as nutrient traps, provide efficient nutrient cycling within a highly diverse aquatic biocoenosis and offer a sustainable environment for efficient nitrogen fixation (Milan \& Margraf, 1994). Besides 
environmental and socio-economic considerations, sustainability considerations have been of great interest during the gradual development of Rainforestation farming for landscape ecology restoration (Goltenboth, 2011). With Rainforestation implemented, there is a great chance for the adopters to alleviate their status in life. With Rainforestation, willing adopters would have greater chances of accumulating greater harvests or bigger yields. With this at hand, there would also be greater assurance of the availability of food all year round because of the availability of support to farmers from the natural environment as well as more peaceful lives because of the availability of native trees to combat the effects of climate change. Hence, Rainforestation would give its adopters the opportune space to indulge into a form of a development which would be sustainable in the long run.

Furthermore, Rainforestation, as an environment-conservation innovation, has also served as an instrument for income generating opportunities and good governance which make the life of its adopters better. According to Compendio and Bande (2017), the innovation of natural resources as an offshoot of the Rainforestation reforestation strategy has brought considerable amount income to its adopters by serving as providers of native tree seedlings to the Philippines' National Greening Program (NGP) as well as private corporations who have wanted to contribute to the thrust of reforesting denuded lands for the future generation. Aside from that, the existence of a people's organization formed solely for the purpose of protecting what is left of the natural environment has also served as a locus for the development of the practice of good governance among the organization's officers and members which take the form of the proper distribution of responsibilities among its members as well as decision making among its officers. The adoption of Rainforestation as an environment conservation strategy has led to the restoration of forests quality in the area of the pioneering adopters which has also led to the improvement of water quality in the river near their area which allowed them to have a good source of water for their farms all year long. This also enabled the adopters to have access to free viand due to the return of fresh water fresh in their river. These are manifestations that Rainforestation serves as an instrument for sustainable development for willing adopters who have been mostly smallscale farmers (Fernandez \& Bande, "Sustainable development through environmental education: From the perspectives of past and present group and individual rainforestation adopters", 2018).

Since its introduction, Rainforestation was disseminated by Visayas State University and was declared one of the official reforestation methods of the Philippines' Department of Environment and Natural Resources (DENR) in 2004. As mentioned earlier, Rainforestation was also designed to provide a staggered income from high-value timber, fruit trees, spices, and medicinals. To add to that, the technology had also increased biodiversity in Rainforestation sites since it helped restore soil productivity and protected the watersheds on degraded sites (Schneider, Ashton, Montagngini, \& Milan, 2013).Hence, at the start of the early 1990 's, a number of Rainforestation sites had been established in the different parts of the country. For the purpose of this paper, this study would delve into case studies among the successful Rainforestation adopters from the different parts of the Visayas region in the Philippines and find out how Rainforestation had affected their lives in particular and the community surrounding their Rainforestation farms in general.

There are four adopters taken into consideration in this study. They are Mr. Manuel Posas of Baybay City, Leyte, Mr. Rene Vendiola of Liptong, Bacong, Negros Oriental, Mayor Eufracio Maratas of Pilar, Camotes, Cebu, and Mr. Romeo Gutang also of Pilar, Camotes. Mr. Posas is considered to be a respondent of this study since he was one of the first persons who 
responded to the call to engage in Rainforestation. After a series of trainings conducted by Visayas State University, Mr. Posas decided to plant native trees in his denuded and empty lot in the mid 1990s. Hence, Mr. Posas is considered to be one of the pioneering Rainforestation adopters. Mr. Rene "tatay Eti" Vendiola is also considered a respondent of this study because of this contribution to nature conservation awareness in Negros Oriental. As a former slash and burn famer, Mr. Vendiola had a metanoia and decided to establish a mini forest using the principle of Rainforestation in a less than a hectare property in his locality in the year 2008. At present his mini forest has served as a home to endangered bird species and also served as a living testament that a single individual could do something great for nature conservation.

Mayor Eufracio "Dodong" Maratas is considered to be a respondent in this study because he is one of the few locally elected municipal officials to seriously take nature conservation into consideration. Through his term as Councilor, Vice Mayor and Mayor of the island municipality of Pilar, Camotes, Cebu, he has always been mindful of taking care of what remains of the natural resources in his municipality. Not only that, he also inspired individuals to follow his lead. These individuals have also done something significant in the environment conservation efforts in their island. One of said individuals is Mr. Romeo Gutang who is also considered as a respondent in this study. By profession, Mr. Gutang is an elementary school teacher who became a citizen of Pilar by virtue of marriage and profession a number of years back. As a new citizen of Pilar, he has always wanted to contribute to the well being of the island's natural resources. With this, he personally took matters into his own hands. He established a mini forest composed of trees endemic to the islands in 2011. At present, his vibrant forest has served as the best visual aid there is in his locality. Mr. Gutang's mini forest demonstrates that it is not impossible to do something for the betterment of the natural environment.

The first adopter delved into in this study is Mr. Manuel Posas of Barangay Marcos, Baybay, Leyte. Among the four successful adopters considered in this study, he was the first to adopt Rainforestation in 1995. Mr. Posas had successfully converted an idle and denuded grassland into a small forest full of Philippine native trees that also gave him a source of potable water. The second adopter considered in this study would refer to Mr. Rene "Tatay Eti" Vendiola of Barangay Liptong, Bacong, Negros Oriental. Mr. Vendiola's Rainforestation farm had served as an inspiration for many Negrense to also adopt Rainforestation since his Rainforestation farm had given him the opportunity to venture into eco-tourism because of the evident restoration of biodiversity in his area. With his success in Bacong, Mr. Vendiola has expanded his Rainforestation efforts to his thirty hectare property in Mantikil, Siaton, Negros Oriental, a mountain barangay located approximately eight hundred sixty meters above sea level.

The third adopter in this study points to Mayor Eufracio "Dodong" Maratas of Pilar, Camotes Island, Cebu. As a public servant, Mayor Maratas acquired his interest in Rainforestation way back to the years when he was still a councilor in his municipality in the year 2000. Mayor Maratas was convinced with the idea of Rainforestation since he perceived it as a way to save and sustain the watershed areas in his island municipality and to also help prevent the impacts of storms and cyclones which often pass by his place. With this, Mayor Maratas made use of his office to link with the academe and the different government and non-government agencies that helped him in his drive for the conservation of the remaining forests and other natural treasures found in his island municipality.

The fourth adopter that this is taken into consideration refers to Mr. Romeo Gutang of Pilar, Camotes Island, Cebu who has a significant contribution in the realm of environment 
conservation in his new home, Pilar, Camotes, Cebu. Mr. Gutang is school teacher at Dadap Elementary School in Pilar, Camotes. As an educator for very young pupils, Mr. Gutang has realized that one of the ways to encourage people to care for Mother Nature is to start the advocacy for nature conservation by starting it himself. In 2012, he succeeded in involving the pupils, and later on, the parents to start creating a forest out of a piece of a rocky land scarcely planted with very old and almost unproductive coconut trees. At present, the result of his efforts is discernible in Camotes Island. Yet, said efforts were met with challenges from the start both caused by humans and nature.

Hence, in order to decipher how these Rainforestation adopters have become successful in their drive for nature conservation, their individual stories are delved into through their individual lived experience. Said experiences would enable the readers of this work to fully understand that it is not impossible for one person to do his or her share in making a significant contribution of saving the natural environment. With this, this paper would investigate into the details of why the adopters have adopted rainforestation when it was introduced to them out of nowhere. This study also examines into the essence of the challenges that said adopters met during the implementation stage of their rainforestation farms. Lastly, this study also inquires into the adopters' causes of success as well as benefits that the successful adopters have enjoyed years after implementing their Rainforestation farms.

\subsection{Methodology}

In the thrust to determine the reasons for success and the contributions to sustainable development of the Rainforestation adopters considered in this study, this research makes use of the qualitative descriptive method. This method's value is based on the premise that problems can be solved and practices improved through observation, analysis and description (Koh \& Owen, 2000). This study finds it fit to utilize the qualitative method since it involves a rich collection of data from various sources to gain a deeper understanding of individual participants, including their opinions, perspectives, and attitudes. It collects data qualitatively, and the method of analysis is also primarily qualitative. This often involves an inductive exploration of the data to identify recurring themes, patterns, or concepts and then describing and interpreting those categories (Nassaji, 2015). Specifically, qualitative descriptive method needs to be the design of choice when a straight forward description of a phenomenon is desired. It is an approach that is very useful when researchers want to know, regarding events, who were involved, what was involved, and where did things take place. The goal of qualitative descriptive method is a comprehensive summarization, in everyday terms, of specific events experienced by individuals or groups of individuals (Lambert \& Lambert, 2012).

In the process of identifying the successful individual adopters of Rainforestation technology from the Visayas region in the Philippines, this study makes use of available data from the Institute of Tropical Ecology and Environmental Management of Visayas State University in Baybay, Leyte, Philippines. In this study, purposive sampling is utilized to narrow down the respondents into four individual Rainforestation adopters. Regarding the use of sampling in a qualitative descriptive method, virtually any purposeful sampling technique may be used. Like any other qualitative research design, the goal is to obtain cases deemed rich in information for the purpose of saturating the data (Lambert \& Lambert, 2012). On the one hand, data collection of qualitative descriptive studies focuses on discovering the nature of the specific events under study. Thus, data collection involves minimal to moderate, structured, open-ended, individual or focus group interviews. On the other hand, 
data collection also may include observations, and examination of records, reports, and documents. Data analysis of qualitative descriptive research, unlike other qualitative approaches, does not use a pre-existing set of rules that have been generated from the philosophical or epistemological stance of the discipline that created the specific qualitative research approach. Rather, qualitative descriptive research is purely data-derived in that codes are generated from the data in the course of the study. Like other qualitative research approaches, qualitative descriptive studies generally are characterized by simultaneous data collection and analysis (Lambert \& Lambert, 2012). Hence, in the course this research, key informant interviews with open-ended questions are employed. In doing this, the researcher visited the four research respondents and set up an interview in a manner that the respondents find most comfortable. The interviews have been unstructured, casual, and conversational. Aside from the said things, this study also makes use of literatures pertaining to Rainforestation so that data derived from the said documents could further contribute to make each case taken into consideration very understandable to the readers of this work.

During the course of the interview, the following questions were asked: What were the reasons why you had adopted rainforestation when it was introduced to you out of nowhere? What were the challenges that you had encountered during the early years of rainforestation implementation? What were the benefits that you had gained and enjoyed years after implementing your Rainforestation farms? The researcher gained permission to digitally record the interviews. Digital recording allowed the researcher to focus on the interview, attend to the participants, record memos and accurately captured participants' tone, inflections, and pauses. After the data were gathered from several sessions of key informant interviews, thematic analysis was done order to identify themes that have emerged from the data from the interviews. The process began with the immersion in the data through reading and re-reading in order to engage with the meaning of the texts for interpretation that facilitated coding (Van Manen, 1990). After the process of data interpretation, the researcher assessed the trustworthiness of the data analysis by presenting the study's interpretation to the respondents. As a qualitative method, this research embarked on several sessions of key informant interviews for clarification and validation of data. Hence, the final draft of this study has been presented to the respondents for their appraisal. Lastly, consent to publish the respondents' answers to the interview questions have already been given by the respondents themselves.

\subsection{Results and Discussions}

\section{Case 1: Mr. Manuel Posas}

\section{Reasons for Adopting Rainforestation}

Mr. Manuel Posas of Barangay Marcos, Baybay, Leyte got himself involved in the Rainforestation project because of the intention of putting into use his piece of land which was barren, denuded, and unproductive for a long time. According to Mr. Posas, he tried many times to utilize his barren land. Yet, Rainforestation which espoused the advocacy of planting Philippine native tree species was the only technology that succeeded in putting his land into use. However, before he committed himself to the rainforestation program, he convinced himself that he had to keep up with the challenge that planting trees and valuable crops would usually met.

\section{Challenges and other obstacles in implementing mechanisms of Rainforestation.}

One of the challenges that he faced in the earlier years of his rainforestation implementation was to put his neighbours' carabaos and other ruminants in check. Not only that, Mr. Posas also considered the unpredictable weather conditions 
of Baybay, Leyte as another challenge that may affect his Rainforestation farm. Lastly, Mr. Posas also considered elements of human undesirable activities as another significant challenge since some people in his neighbourhood had the tendency to cut young trees for fuel as well as other people's behavior of doing harm to things which were not theirs. Nevertheless, Mr. Posas did not lose hope that his unutilised land would be put into use. Through the years, he was able to address said challenges and his rainforestation farm is presently standing proud at the hillsides of Barangay Marcos, Baybay, Leyte.

For Mr. Posas, the turning point that enabled him to make full use of his land was his opportunity to attend a seminar organized and conducted by Visayas State University (VSU), and the German Technical Cooperation Agency (GTZ) in 1994. It was there that he learned about Rainforestation farming or the integration of native forest tree species into agricultural farms, vacant non utilized lands, or unproductive and denuded lands to make such lands useful and sustainable. In 1995, Mr. Posas decided to develop his unproductive land that was less than a hectare in area located at Barangay Marcos, Baybay, Leyte. The property was predominantly a grass land at the start. According to him, the success of his rainforestation efforts could be attributed to the expert and logistical support from VSU and GTZ as well as his conviction to make the Rainforestation program succeed. With said things at hand, he was able to grow native tree species together with fruit trees and high value crops in his formerly denuded land. Mr. Posas had planted a total of 660 trees with 8 pioneer tree species, 4 dipterocarp tree species, and five fruit tree species. At present, Mr. Posas's Rainforestation farm is still vibrant with healthy native trees, productive fruit trees, and a variety of high value crops that provided him with additional income.

\section{Current state and future plans}

At present, Mr. Posas is already reaping the fruits of his labors. The most important thing that nature has given him is the resurgence and presence of clean and potable water in his Rainforestation farm. According to Mr. Posas, water was very scarce and difficult to access in his place before he started Rainforestation in the early 1990's. However, 12 years after he established his Rainforestation farm, Mr. Posas observed the emergence of fresh water form at the slope of his farm. Using a part of his retirement pay, Mr. Posas made a water system which presently supplies clean and safe water to 20 households in his community. It gives Mr. Posas permanent access to potable and safe water, enabled him to irrigate his rice field near his Rainforestation farm, and provides him the opportunity to earn extra income since he asked a minimal fee from those who accessed water from his newly established water system.

Moreover, Mr. Posas also claims that his Rainforestation farm has also greatly improved the quality of air in his area. Furthermore, he has also accumulated income from the sales of fruits from his fruit trees. The leaf litters from the mature native trees in his Rainforestation farm have served as natural fertilizers making his farm's land fertile that enable the fruit trees to bear much fruit. Lastly, Mr. Posas is proud to declare that his personal intention of just making his small denuded land productive has made a little contribution to the thrust of nature conservation. According to him, there is also evidence of the return of a number of bird species, bats, and reptiles in his rainforestation farm. In my initial interview with Mr. Posas, he has not mentioned about the kinds of birds that fly around his denuded land before rainforestation implementation. After all, only a few birds would like to stay in an empty piece of land. Yet, at present, Mr. Posas claims that there are species of local hawks and predator birds that lurk in the vicinity of his rainforestation site. This makes a lot of sense since native trees are home to 
Table 1. List of dipterocarp native trees with their corresponding scientific names planted in the Rainforestatioin farm of Mr. Manuel Posas in Barangay Marcos, Baybay City, Leyte (Ceniza, Milan\& Acabal, 1998).

\begin{tabular}{cl}
$\begin{array}{c}\text { The } 4 \text { dipterocarp tree species planted in Mr. Posas' } \\
\text { Rainforestation site }\end{array}$ \\
Name of Native Tree & Scientific Name \\
\hline Apitong & Dipterocarpus warburgii \\
Dalindingan & Hopea plagata \\
Yakal Kaliot & Hopea malibato \\
Bagtikan & Parashorea malaanonan \\
\hline
\end{tabular}

Table 2. List of pioneer native trees with their corresponding scientific names planted in the Rainforestatioin farm of Mr. Manuel Posas as confirmed by Dr. Marlito Bande, co-author of this paper.

\begin{tabular}{ll}
\hline \multicolumn{2}{c}{$\begin{array}{c}\text { The } 8 \text { pioneer tree species planted in Mr. Posas' } \\
\text { Rainforestation site }\end{array}$} \\
Name of Native Tree & Scientific Name \\
\hline Kalumpit & Terminalia microcarpa \\
Toog & Peterianthus quadrialatus \\
Dao & Dracontomelon dao \\
Narra & Pterocarpus indicus \\
Molave & Vitexparviflora \\
Antipolo & Artocarpus blancoi \\
Tindalo & Afzelia rhomboidea \\
Bitanghol & Calophyllum blancoi \\
\hline
\end{tabular}

Table 3. List of fruit trees with their corresponding scientific names planted in the Rainforestation farm of Mr. Manuel Posas as confirmed by Dr. Marlito Bande, co-author of this paper.

\begin{tabular}{cl}
\hline \multicolumn{2}{c}{ The $\mathbf{5}$ fruit trees species planted in Mr. Posas' Rainforestation site } \\
Name of Fruit Trees & Scientific Name \\
\hline Durian & Durio zibethinus (introduced) \\
Lansones & Lansium domesticum (introduced) \\
Mangosteen & Garcinia mangostana (introduced) \\
Marang & Artocarpus odoratissimus (introduced) \\
Nangka & Artocarpus heterophyllus (introduced) \\
\hline
\end{tabular}


a variety to prey bird species. When ask about the specifics, Mr. Posas politely admit that he is not in the position to give detailed description of birds or bats that are discernible in his Rainforestation site since he is not an ornithologist (expert on birds) nor a chiropterologist (or an expert in bats). What he is asserting though is that there are sightings of birds, bats and reptiles in the area.

Yet, Mr. Posas also wants to stress that recently, Baybay, Leyte was badly hit by super typhoon Haiyan in November of 2013 and the El Niño phenomenon that hit the entire Philippines in 2015 (Viray, 2015). Despite these two undesirable environmental events, Mr. Posas's Rainforestation farm is still standing which is a living testament that native tree species could stand to the most unfriendly and harshest weather conditions of the country. For Mr. Posas, this capacity could mitigate environmentrelated disasters like soil erosions and landslides since native tree species are highly adaptable to the harsh weather conditions of the country. However, Mr. Posas has no plans to stop in disseminating to the public that it is not impossible to do something for the natural environment. He is still very willing to share what causes him to indulge and become successful in conserving nature through his Rainforestation site to every visitor that visits his site. For him, it is a way of giving back to nature since nature has provided him things that makes life more enjoyable and a lot easy for him.

\section{Case 2: Rene "Tatay Eti" Vendiola Reasons for Adopting Rainforestation}

Mr. Rene Vendiola of Bacong, Negros Oriental had adopted Rainforestation simply because of the reason that he wanted to make a forest in his backyard so that he could live near it. This reason is quite understandable since Mr. Vendiola used to guide tourists, mostly foreigners, to the mountains of Negros Oriental. As a former tourist guide for foreigners who wanted to climb the mountains of Negros Oriental, Mr. Vendiola already formed the habit of collecting native tree wildlings and planted it to his property near his house. However, his efforts in planting native tree species failed many times that for years he kept on planting again and again until in 1994, he first succeeded in planting his first native tree, Guisok-guisok (Hopia Philippinensis). In 1999, he again succeeded in planting his first White Lauan (Shorea Contorta).

Yet, upon having the chance to attend Yale University's Environmental Leadership Training Initiative at Visayas State University, Mr. Vendiola's knowledge on planting native trees was reinforced and he used it to set up a Rainforestation farm at the vicinity of his house. Later, Mr. Vendiola had expanded his Rainforestation efforts to his thirty hectare property at Barangay Mantikil of Siaton, Negros Oriental which is located a little over eight hundred meters above sea level. After completing Yale University's Environmental Leadership Training Initiative seminar at Visayas State University in 2004, Mr. Rene Vendiola returned home with the conviction that he would make a rainforestation farm of his own in his less than a hectare property at Liptong, Bacong, Negros Oriental. In 2005, Mr. Vendiola started to establish his Rainforestation farm which he also planted with a number of fruit trees.

\section{Challenges and other obstacles in implementing mechanisms of Rainforestation.}

Mr. Vendiola's drive to plant native tree species in his property was met with stern opposition from his wife. Mr. Vendiola's wife objected to the intention of Mr. Vendiola since the property that he planted his native trees was also planted with productive coconut trees. For Mr. Vendiola, it was more of a personal challenge since his relationship with his wife was very affected to the extent that he and his wife developed communication problems that lasted for six months. Not only that, Mr. Vendiola started his Rainforestation farm on his own with no financial assistance from established institutions. 
Hence, he had to collect seedlings and wildlings by himself in which the expenses in the process of seedling and wildling collection were personally shouldered by him.

Aside from that, his drive to plant more was limited due to his lack of knowledge on the technical aspect of planting and propagating native trees. According to Mr. Vendiola, his first shot to succeed in his interest in planting native trees arrived in 2004 when he was given the opportunity to attend Yale University's Environmental Leadership Training Initiative conducted at Visayas State University. Despite the uncertainty of the outcome, he pursued to attend the training. For Mr. Vendiola, the training gave him a working and technical knowledge about the best practices in planting trees and he wasted no time to establish a nursery when he arrived in Negros, and a year later, established his Rainforestation Farm. Yet, for Mr. Vendiola, what fuelled his desire to go on with environment conservation efforts was his dedication and commitment to plant and propagate the almost extinct native tree species of the Philippines for the future generation to see and appreciate. In the thrust of expanding the number of native tree species planted in his area, Mr. Vendiola has first planted the same native tree species planted by Mr. Posas since Mr. Posas' site has served as a demonstration farm for would be Rainforestation adopters who train in Visayas State University.

\section{Current state and future plans.}

At present, Mr. Vendiola's Rainforestation farm serves as an eco-tourism destination for foreign and local tourist in Dumaguete City area in Negros Oriental. Not only that, the fruit trees that Mr. Vendiola had planted with the native trees had also given Mr. Vendiola another source of income during the trees' fruiting season. The success of Mr. Vendiola's Rainforestation efforts has opened a lot of opportunities for him. Yet, these opportunities have been triggered mainly because of the vibrant forest landscape of his Rainforestation farm as well as the evident return of biodiversity in his area. Though Mr. Vendiola's reason for adopting Rainforestation in the 2004 was simply because he wanted to make a forest and live near to it, Rainforestation gave him more than what he had wanted.

Moreover, Mr. Vendiola has also been given a "lecturer" position at the Negros Oriental State University College of Forestry in Dumaguete City because of his deep experience in caring for the environment and planting native trees. With this, students from different parts of the Philippines often visit his Rainforestation farm where he also seized the opportunity to spread the message of the importance of nature conservation to his visitors. Lastly, the Ramon Aboitez foundation, Incorporated has given Mr. Vendiola the prestigious Exemplary Individual Award in recognition for his commitment to build a more humane, equitable, and caring society that have brought change and improved the lives of the less privileged during the 5th Triennial Awards for Visayas and Mindanao icons in March 2012 (Picornell, 2012). Aside from the recognition, this award has also given Mr. Vendiola a considerable amount of cash which he planned to use in his advocacy in environment conservation. Nothing has changed in Mr. Vendiola's plans for the future. According to him, as long as he is alive, he would continue to speak for the interest of the natural environment. He also asserted that he would not use his Liptong Woodland Rainforestation for any other purpose except for environmental conservation. This plan would only be changed if he would no longer have his breath of life since he would no longer be around to decide on it at that time.

\section{Case 3: Mayor Eufracio Maratas}

\section{Reasons for Adopting Rainforestation}

Mayor Eufracio "Dodong" Maratas's reason for adopting Rainforestation was driven by his intention to maintain and sustain the carrying capacity of the 
watershed areas in his island municipality of Pilar, Camotes, Cebu. During his term as councilor of Pilar, Camotes, Mayor Maratas always made it a point to chair the council's Committee for the Environment. For Mayor Maratas, Rainforestation was a strategic direction for an integrated approach to Natural Resources Management of the Island. This paved the way for Mayor Maratas' involvement in environment conservation efforts until the present. As mentioned earlier, Mayor Maratas adopted Rainforestation simply for the reason that he wanted to protect what was left of his island municipality's watershed so that it could sustain the needs of the present and future generations of his constituents.

Mayor Maratas believes that it is not impossible and too late to do something positive for nature conservation. For him, what is important is that one has just to continue his or her drive to make a difference. Not only that, Mayor Maratas also believes that a combination of the technical support from experts from the Visayas State University (VSU) would complement one's hard work since experts' advice could a little bit compensate for what are lacking in relation to the natural resources of the island. Not only that, external help from the government and non-government organizations (NGO) are also factors for the continuance of Rainforestation implementation and adoption since such organizations often give adopters the much needed support which the realm of environment seldom have. Mayor Maratas has asserted that the existence of rainforestation in his island could be also attributed to the Local Government Unit's Partnership with the community. According to Mayor Maratas, the presence of community partners in caring for the native trees gives the trees greater chances of survival.

Challenges and other obstacles in implementing mechanisms of Rainforestation.

As a government official involved in environment conservation, one of the challenges that he saw with regards to his rainforestation efforts was the type of soil in his island. His island's soil is mostly made up of lime which is not a fertile type of soil. As a result, the native trees that he planted found it difficult to grow fast. Not only that, Pilar Camotes is also a frequent typhoon path which also affected his planted tree species. This was experienced during the visit of Typhoon Haiyan to the country in 2013. To add insult to injury, El Niño hit the Visayas in 2015 which affected the survival of the trees in his rainforestation farm. Mayor Maratas also added that another challenge for environment conservation is the politics of a certain locality. According to Mayor Maratas, the political situation in a place could affect a local government's policy towards nature conservation may it be in the positive or in the negative. For instance in Pilar, one people's organization (PO) that used to be active just abruptly cease to function immediately after the Philippine National and Local elections in 2016. Differences in principles between the new elected LGU officials and the officers ofthe said people's organization has caused the organization to function well. It has led the organization to cease existing. Hence, political affiliations of the people involved in conservation projects have also been referred to as one of the challenges in the implementation of the Rainforestation project.

\section{Current state and future plans}

Mayor Maratas has many times asserted that the rainforestation program has become an instrument in mainstreaming water, soil, and biodiversity conservation that led to a bigger constituency among the citizens of his island municipality including youth and children. It has also paved the way to the island municipality's upstream and downstream collaboration in such a way that it teaches stakeholders --- fishermen who double as farmers ---- not to destroy what are left of the trees in their mountains during the times when the seas are unfavorable for fishing. In that 
way, they could sustain the source of water in their locality. Moreover, Mayor Maratas has proven that native tree species like the White Lauan (Shorea Contorta), Narra (PtercarpusIndicus), and Yakal (Shorea Astylosa) could survive in his island under very harsh conditions. This confirms Milan and Margraf's hypothesis which claims that reforestation in the humid tropics would be more successful and sustainable if reforestation efforts would use the species of trees that composed the original rainforests in the area (Milan \& Margraf, 1994). Mayor Maratas sees rainforestation as "good politics" in such a way that when people see a government official work for the betterment and well-being of his constituents, they will give him their trust and support. This is evidenced in Mayor Maratas' political journey. From a municipal councilor who chairs the Committee on the Environment in the year 2000, he became a Vice Mayor, and became Mayor of Pilar until May 2018. Lastly, Mayor Maratas has also categorically stated that he will continue his advocacy in protecting what is left of the natural environment in the immediate and remote future.

\section{Case 4: Mr. Romeo Gutang Reasons for Adopting Rainforestation}

The reason behind Mr. Romeo Gutang's involvement in Rainforestation is simply his desire to do something to conserve the environment in his new-found home of Pilar, Camotes Island, Cebu. Mr. Gutang's observation when he started to get himself involved in environment-related conservation efforts was that the average citizen of Pilar simply did not give priority or give due importance to the natural environment. As an elementary school teacher, his vision was simply to set an example to his young pupils so that he could give life to what he was preaching in the classroom in relation to the aspect of environment conservation. Hence, by starting to plant native tree species in a rocky and almost unproductive land planted with very old coconut trees, he was able to convince his pupils and his pupils' parents to join him in his efforts to make a forest out of Philippine native tree species.

According to Mr. Gutang, one of the reasons that he persisted in his goal to establish a rainforestation site could be attributed to the support of the Local Government Unit of Pilar Camotes through the efforts of the then councilor Eufracio Maratas. It was also accompanied by the sudden change of heart of many community members who had not previously supported his efforts. His first felt that he could succeed in his endeavors when he was able to convince his pupils' parents that they would plant trees together in a two hectare property near their school campus so that trees could support and sustain the island's water source and provide clean air in the Pilar Camotes area for many years to come. To address the unfertile land in his area, Mr. Gutang followed the advice of then Councilor Maratas to use tree species that were endemic in the islands so that they could easily adapt to the harsh weather conditions of the place. Hence, Mr. Gutang made of use of planting materials from Magtalisay Trees (Terminalia Catappa) which grow in abundance in the remaining forests of Pilar, Camotes. Not only that, Mr. Gutang also planted Narra (PtercarpusIndicus) and Yakal (Shorea Astylosa) tress since they were proven to survive in harsh weather conditions as demonstrated in Mayor Maratas' Rainforestation farm.

\section{Challenges and other obstacles in implementing mechanisms of Rainforestation}

Implementing Rainforestation had also its share of challenges. The Challenges that Mr. Gutang met during the early years of rainforestation came from both nature and humans. Mr. Gutang attributed nature as his first challenge since the land in his rainforestation area was very rocky and not fertile because it was mostly composed of lime. It was very difficult to grow trees, yet he persisted and believed that rainforestation could still be done. Not only that, a year after he started his rainforestation farm 
in 2012, Typhoon Haiyan visited in 2013 and affected much of the young trees that he planted. To add to that, Visayas was hit by the El Niño phenomenon in 2014 which required him to personally water his young trees otherwise the trees would die. The second challenge for Mr. Gutang was that his effort to establish a rainforestation farm was not initially supported by the members of his community. Hence, at the very start, he established it alone with no support from the community and no financial assistance from established organizations.

\section{Current state and future plans}

At present, Mr. Gutang is happy with the presence of his vibrant rainforestation farm. For him, it is a great stress reliever. It also improved biodiversity in the area since birds are already very discernible and the area has also become a bit colder as compared to the times when his rainforestation farm did not yet exist. To add to this, the soil quality in Mr. Gutang's rainforestation farm has also greatly improved since the leaf litters have served as natural fertilizers. Mr. Gutang has planted high value crops inside his rainforestation farm which have often times provided him free vegetables, banana fruits, and a little income from the sales of the surplus. Moreover, Mr. Gutang has also observed that his rainforestation project has a great potential for disaster mitigation since his young trees had survived the onslaught of Typhoon Haiyan in 2013 and the El Niño phenomenon in 2015.

Mr. Gutang has also realized that his rainforestation farm has a great potential for ecotourism for local and foreign tourists have started to visit the beautiful island municipality of Pilar, Camotes, Cebu. For his part, Mr. Gutang plans to establish another Rainforestation site to any land that its owner would allow him to. Of course, Mr. Gutang has expressed that he and the land's owner should make some form of agreement in order to make the rainforestation implementation successful. For him, this is his contribution to protect what is left of the natural resources in his new home - Pliar, Camotes, Cebu.

\section{Emerging Themes}

1. Environmental Conservation and Protection. From the four case studies delved into, the four successful adopters share the same reason on why they had adopted Rainforestation when it was introduced to them in the early 1990s and the early 2000s. All of them adopted Rainforestation mainly for environmental conservation and protection. Mr. Posas, for instance, just wanted to restore a small denuded piece of land and turned out having a small vibrant forest of his own more than a decade after Rainforestation implementation. Mr. Vendiola just wanted to make a small forest out of native trees in his backyard in order to preserve the dwindling native tree species and live in the midst of his man-made forest. Yet, after a decade of adopting rainforestation, he turned out to have a forest that has served as an eco-tourism hub and a haven for bird watchers in Negros Oriental in the Philippines. Mayor Maratas' involvement in Rainforestation was solely aimed at protecting the watershed areas in the island municipality of Pilar, Camotes, Cebu while Mr. Romeo Gutang initially get involved in planting trees in his new found home for the purpose of contributing to the thrust of improving the quality of air in the island municipality by planting trees endemic to his place. As discernible from the four adopters' reason to engage in environmental conservation, it is quite obvious that conservation is about both people and nature. In the study of Pearson (2016), it is observed that all societies throughout human history have tackled the dual goals of conserving nature because of the services provided by their benefit and because of nature's intrinsic values.

2. Environmental Benefits. Common among the four individual Rainforestation Adopters is the enjoyment of environmental benefits years after they adopted Rainforestation. All four adopters 
have acknowledged that quality of air in the vicinity of their established Rainforestation farms have greatly improved as well as the consistent return of biodiversity in the area. This claim coincides with the findings of a 2010 research series which has asserted that science has confirmed that trees have served as instruments in improving air quality and the lives and health of people living therein. Said study also has also claimed that trees help mitigate the effects of air pollution, enable people to conserve energy by cooling the vicinity in which they live as well as affect human comfort and health (Novak \&Heisler, 2010). Not only that, soil qualities in the Rainforestation sites have also become fertile and make them already plantable for cash and high value crops. To add to this, a water source has emerged from the Rainforestation farm of Mr. Posas because of the presence of the native trees after twelve years of planting making water available to Mr. Posas all year round. This spectacle that occurred at Mr. Posas's Rainforestation farm coincides with the research findings of Meerveld, Zhang, and Bruijnzeel (2014) which suggested that reforestation (Rainforestation) can largely restore hydrological functioning of degraded sites if the forest is allowed to develop over a sufficiently long period without subsequent disturbance.

3. Economic Benefits. The above-mentioned environmental benefits have led the adopters to enjoy the economic benefits of the success of their established Rainforestation farms. For instance, because of the improvement of soil quality in the Rainforestation areas, Mr. Posas, Mr. Vendiola and Mr. Gutang have been able to plant fruit trees and cash crops in their Rainforestation farms. During harvest season, all three of them have enjoyed economic gains from the sales of the fruits, vegetables and root crops from their harvest. Not only that, said adopters have also economically benefitted from other sources. For Instance, Mr. Posas' water source has enabled him to irrigate his nearby rice field and enabled him to plant rice all year round. To add to this, he has also been able to share the surplus of his water from his water source to his neighbors and enabled him to collect a just amount as a fee to the water provider. Moreover, because of the return of biodiversity in Rainforestation sites, Mr. Vendiola has turned his Rainforestation farm into a famous eco-tourism site and a haven for bird watchers that come from all over the world. The return of the almost extinct bird species like the Negros Scops Owls (Otus Negrorum) and the black belted flower picker (Otusnigrorum) in his Rainforestation farm has given Mr. Vendiola a considerable amount of income from foreign and local bird watcher tourists. In fact, just last March, 2018, a bird thought to be extinct for more than one hundred years found its way to Mr. Vendiola's Rainforestation farm. The new bird visitor on the floor of Mr. Vendiola's man-made forest made of Philippine native trees turned out to be a blue-winged pitta (P. moluccensis), a species that was recorded only twice in the Philippines in Palawan province in January 1898 and Basilan province in February 1907, according to the "A Guide to the Birds of the Philippines" by Robert S. Kennedy et. al. (Bajarias, 2018).This means economic gains from the entrance fees generated from the tourists. Aside from that, Mr. Vendiola has also been awarded a Triennial Award from Ramon Aboitez Foundation as well as other government and non-government agencies which enabled him to accumulate more than half a million pesos in cash prizes. Lastly, Mr. Gutang has economically gained from his Rainforestation sites since the Department of Education (DepEd), Cebu Province Division has recognized the contributions of his Rainforestation sites and environmental conservation activities. Because of this, he has been promoted to a much higher rank in his job that enabled him to have bigger income this time around.

4. Social Benefits. All of the adopters delved into in this study have also socially benefitted from the success of the Rainforestation farms. Yet, it is Mayor Maratas who has greatly benefitted from the 
social aspect since it was not only him who enjoyed the benefit but his constituents as well. According to Mayor Maratas, Rainforestation has enabled him to mainstream water, soil, and biodiversity conservation that led to a bigger constituency among the citizens of his island municipality including youth and children. It has also paved the way to the island municipality's upstream and downstream collaboration in such a way that it teaches stakeholders --- fishermen who double as farmers ---- not to destroy what are left of the trees in their mountains during the times when the seas are unfavorable for fishing so that they could sustain the source of water in their locality. Mr. Vendiola, Mr. Posas and Mr. Gutang have also socially benefitted from the success of their Rainforestation farms since it has given them a chance to educate people of all ages about the importance of environment conservation. Since all their respective farms are frequently visited by people who have wanted to see for themselves that planting and growing native tree species are doable and possible, Mr. Vendiola, Mr. Posas and Mr. Gutang have also interacted with said people and have the chance to share their knowledge to them as well as learn also from their visitors' experiences. These benefits are confirmed and validated through the findings of the study of the Institute for European Environmental Policy which asserted that environmental conservation benefits people socially through giving people insights on how policies on environmental conservation and protection have paved the way for the people's enjoyment of more pleasant, peaceful and less stressful environments. Such policies boil down to providing people with other social benefits such as interacting with other people from different walks of life as well as providing them with green public spaces that reduce social tensions (ten Brink, et al., 2016).

\section{Overcoming Challenges as a Key Element in} the Successful Implementation of Rainforestation. All four Rainforestation adopters have recognized that a very important element for a successful Rainforestation adoption has been overcoming challenges of all kinds. There have been three kinds of challenges identified by the adopters themselves: 1. Challenges brought about by humans. 2. Challenges of financing and sustaining the project. 3.Challenges brought about by the natural environment. For instance, Mr. Posas has first found it difficult to make his native trees grow since he has first to put his neighbors domesticated animals in check. Mr. Vendiola's thrust of converting his backyard planted with coconut trees into a miniforest has been greatly resisted by her wife who put a challenge on their married life for quite some time. Mr. Gutang's efforts of planting native trees have first been met by criticism and ridicule by some of his neighbors. Mayor Maratas' thrust to implement environmental conservation projects through Rainforestation in the island municipality of Pilar has been, at times, interrupted, due to some political differences among members of the Pilar Municipal Council. Another challenge has been the invalidity of funds to sustain the Rainforestation project by two of the adopters during the maintenance stage as well as the challenge brought about by the natural environment through cyclones and droughts in recent years. Yet, the four adopters have manifested that such challenges could be overcome if there is a will to succeed as evidenced by the presence of the Rainforestation farms in their respective areas. Accompanied with the assistance of Visayas State University and a non-government organization, the Environmental Leadership Training Initiative (ELTI), challenges posed by environmental and financial factors have been addressed in some ways. With regards to the challenges brought about by the natural environment, this challenge has been addressed by the native trees themselves since they are more adaptable to the country's weather conditions, and thus, has the tendency to survive in relation to the environmental challenges of the country. 


\subsection{Conclusion}

This study concludes that native trees endemic to the Philippines have the ability to adapt to the harsh weather and soil conditions of the country. This characteristic of Philippine native tree species has enhanced the viability of Rainforestation as a major reforestation conservation strategy in the Philippines. This is discernible in the vibrant rainforestation demonstration farms of Mr. Manuel Posas, Mr. Rene Vendiola, Mayor Eufracio Maratas, and Mr. Romeo Gutang which are all standing proud in their respective localities. With this adaptability, the adopters also believe that rainforestation could also mitigate environment-related disasters since native trees' capacity to adapt to the harsh conditions of the country could also lessen the chances of soil erosions and landslides to occur. Moreover, this paper also concludes that common among the four Rainforestation adopters' reason for success points out to the technical assistance and expert advice provided to them by the Environment Leadership Training Initiative (ELTI) and the Visayas State University. Yet, said adopters have also stressed that the element of hard work, perseverance, and a strong belief in oneself that one could make a difference in nature conservation cannot also be just set aside as a major contributing factor to the success of Rainforestation.

Furthermore, this study also concludes that Rainforestation has shown the possibility to achieve its intended end of promoting conservation and sustainable development. This claim is discernible in the environmental benefits that the adopters have enjoyed as offshoots of the success of the implementation of their Rainforestation farms. On the one hand, the success of the growth of Philippine endemic tree species in the four adopters 'rainforestation farms has manifested the achievement of the objective of conservation. This is reinforced by the upstream and downstream collaboration among Mayor Maratas's constituencies in protecting what are left of the tress in the watershed areas of their island municipality which is a manifestation that Rainforestation would not only bring environmental benefits but also the enjoyment of social benefits to its willing adopters.

On the other hand, this study also concludes that sustainable development has been manifested in the adopters' opportunities to acquire extra income from the produce of their rainforestation farms like the sales of fruits from the fruit trees that have been planted together with the native trees, the access to safe and potable water as discernible in Mr. Posas's Rainforestation farm, the improvement of the quality of air in the area as claimed by the successful adopters, the improvement in soil fertility as provided by the leaf litters, and the improvement of biodiversity as discernible in the return of wildlife, birds, bats, and reptiles. Though these might not be the perfect manifestations of what sustainble is all about, there are semblances that what the adopters' have acheved have shown semblances of what 1987 Bruntland Commission Report as a "development that meets the needs of the present withoung compromising the ability of the future generations to meet their own needs (Bruntland, 1987)

Lastly, this study also concludes that Rainforestation offers a great venue for eco-tourism which indubitably gives successful adopters a good source of income as manifested in the experience of Mr. Rene Vendiola. These are just a few of the environmental and economic benefits that Rainforestation brings to its willing adopters. Aside from that, Rainforestation also gives the adopters individual personal gains. Mayor Maratas, for instance, has claimed that Rainforestation has led to greater constituency in his island municipality. Mr. Vendiola has been awarded a national recognition for exemplary work for nature conservation, $\mathrm{Mr}$. Posas became a supplier of potable water to his neighbors which makes him a problem solver to his community's need of water supply, while Mr. Gutang has claimed that immersing himself in his rainforestation site naturally relieves him of the 
stress from the rigors of his work. To add to this, Mr. Gutang has also claimed that he has enabled himself to empower others - his pupils and his pupils' parents - to take their share in the thrust of saving the only planet that the world citizens have.

\section{References}

Asio, V. B., \& Milan, P. P. (2002, January). Improvement of soil quality in degraded lands through rainforestation farming. Retrieved from: http:// www.rainforestation.ph/resources/publications. html

Bajarias, A. J. (2018, August 9). Rare Bird Sighted After 111 Years. Retrieved from https://newsinfo. inquirer.net/1019373/rare-bird-sighted-after-111years.

Ceniza, M., Milan, P. and Acabal, O. (1998). Anthropod communities in selected deptirocarp trees in rainforestation sites in Baybay, Leyte, Philippines. Retrieved from: http://www.rainforestation.ph/ resources/publications.html

Comependio, S. J., \&Bande, M. J. (2017). Effectiveness of community-based forest management program as a strategy on forest restoration in Cienda and San-Vicente, Baybay City, Leyte, Philippines. Asian Journal of Agricultural Extension, Economics \& Sociology, 15(4), 1-20.

Fernandez, G., \& Bande, M. J. (2018).Rainforestation implementation and Durkheim's Notion of Mechanical Solidarity: From the experiences of the pioneering adopters of the Cienda San Vicente Farmers Association in Baybay City, Leyte. Journal of Agriculture and Technology Management, 21(1), 1-16.

Fernandez, G. C., \& Bande, M. J. M. (2018). Sustainable development through environmental education:
From the perspectives of past and present group and individual rainforestation adopters. International Journal of Environmental and Rural Development, 9(2), 47-52.

Fernando, E. (2005). Rainforestation: A strategy for restoring our dying forests. (Policy Paper no. 3). Manila, Philippines: Haribon Foundation.

Fernando, E. (2005). Restoring the Philippine Rainforest (Haribon Policy Paper no. 2). Manila, Philippines: Haribon Foundation.

Goltenboth, F. (2005, October 11). Conference on International Agricultural Research for Development. Retrieved from: http://www. rainforestation.ph/Resources/pdf/publications/ Goltenboth_2005_Ecosystem_Approach.pdf.

Goltenboth, F. (2011). "Rainforestation farming" - An Appropriate and Applied Ecological Approach for Landscape Rehabilitation and Impact Mitigation of Climate Change in the Humid Tropics. Annals of Tropical Research, 33(2), 85-106.

Haribon Foundation. (2016). Classifying natural and restored forests containing primary, secondary growth, or residual forests. (Vol. 3). Manila, Philippines: PANAO. Rain Forest Restoration Initiative.

Kalikasan People's Network. (2017). Where are the trees? Examining the state of the Philippine forests. Retrieved from http://www.kalikasan. net/features/2011/06/05/where-are-the-treesexamining-state-philippine-forests.

Koh, E. T., \& Owen, W. L. (2000). Introduction to Nutrition and Health Research. Boston, Massachusetts: Kluwer Academic.

Lambert, V. A., \& Lambert, C. E. (Eds.). (2012). Qualitative 
Descriptive Research: An Acceptable Design. Pacific Rim International Journal of Nursing Research, 16(4), 255-256.

Meerveld, I., Zhang, J., \& and Bruijnzeel, S. (2014). EGU general assembly.InEffects of Reforesting Degraded Grassland on Hydrological Flow Pathways on Leyte, the Philippines. Geographical Research Abstracts.

Milan, P., \& Ceniza, J. (Eds.).(2009). Rainforestation Trainers Manual. Baybay City, Leyte, Philippines: Visayas State University Institute of Tropical Ecology.

Milan, P., \& Margraf, J. (1994). Rainforestation farming: An alternative to conventional concepts. Annals of Tropical Research, 16, 1-11.

Nassaji, H. (2015). Qualitative and descriptive research: Data type versus data analysis. Language Teaching Research, 19(2), 129-135. doi:10.1177/1362168815572747

Novak, D. J., \&Heisler, G. M. (2010). Air Quality Effects of Urban Trees and Parks. Syracuse, New York: National Recreation and Park Association.

Picornell, J. (2012, April 1). Ramon Aboitez Foundation gives out 5th triennial awards for VisayasMindanao Icons. Retrieved from: http://lifestyle. inquirer.net/41865/ramon-aboitiz-foundationgives-out-5th-triennial-awards-for-visayasmindanao-icons/.

Pearson, R. G. (2016). Reasons to Conserve Nature. Trends in Ecology and Evolution, 31(5), 366-371. doi:https://doi.org/10.1016/j.tree.2016.02.005

Pinho, R. C., Miller, R. P., \& Alfaia, S. S. (2012). Agroforestry and improvement of soil fertility: A view from Amazonia. Applied and Environmental Soil Science,
1-11.DOI:http://dx.doi.org/10.1155/2012/616383

Ranada, P. (2014, February 21). Is the government reforestation program planting the right trees? Retrieved August 2, 2017, from http://www. rappler.com/nation/51200-national-greeningprogram-native-trees

Schneider, T., Ashton, M., Montagngini ,F., \& Milan, P. (2013). Growth performance of sixty three species in smallholder reforestation trials on Leyte, Philippines. New Forests. Springer Science Media Dordrech. DOI: 10.1007/s11056-013-9393-5.

Van Manen, M. (1990). Researching lived experience: Human science for an action sensitive pedagogy (2nd ed.). London, United Kingdom: Althouse.

Viray, P. (2015, September 29). PAG ASA: Philippines Experiences Strong El Niño Retrieved from: http://www.philstar.com/ headlines/2015/09/29/1505260/pagasaphilippines-experiencing-strong-el-nino. 